\title{
Clinical Aspects of Pacients with Chromoblastomycosis Treated in a Dermatology Reference Center in the Brazilian Amazon
}

\begin{abstract}
Carla Andréa Avelar Pires ${ }^{1}$, Suzana Maria Klautau Ferreira ${ }^{1}$, Anderson Phelipe Dias Sabry Azar ${ }^{1}$, Rafael Oliveira Chaves ${ }^{1}$, Marcella Silva Maia ${ }^{1}$, Gabriela Ferreira Rocha', Heraldo Hebert Mauro Neto', Ana Carolina Magalhães Nascimento', Márcia Moraes Dos Prazeres', Samira Oliveira Silveira1, Yan Garcia Lira1, Victor Aragão dos Santos ${ }^{1}$, Fernanda Araújo Santos ', Mylla Barral Do Nascimento O' de Almeida ${ }^{2}$
\end{abstract}

\section{Abstract}

Background: Describes clinical aspects of patients with chromoblastomycosis treated at the dermatology department of the Para State University. The present study aimed to describe clinical and therapeutic aspects of patients with chromoblastomycosis treated at the dermatology department of Para State University.

Methods: An observational, descriptive, case series study was performed, comprising 12 patients with the diagnosis of chromoblastomycosis. A clinical interview and a dermatological protocole were applied, classifing these patients in variables as gender, age, time of illness, type of lesion (size, shape, appearance, location and evolution), treatment and complications.

Conclusions: most of the patients were male, rural workers, with vegetative lesions according to the classification of Carrión, graduated as moderate, with less than 10 years of evolution.

\section{Introduction}

Chromoblastomycosis or chromomycosis is a fungal, chronic, polymorphic infection of the cutaneous and subcutaneous tissues caused
1 Universidade do Estado do Pará. Belém, Pará, Brazil.

2 Universidade Federal do Amazonas. Manaus, Amazonas, Brazil

Contact information:

\section{Suzana Maria Klautau Ferreira.}

Address: Universidade do Estado do Pará. Travessa Perebebuí, n²623, Belém. 66095-450 (Brazil).

”suzanamkf@live.com

Keywords

Chromoblastomycosis; Fungi; Dermatology. 
by various species of dematiaceous fungi, histologically shown as sclerotic, brownish or fumagoid bodies [1]. The most frequently isolated organisms are Fonsecaea pedrosoi, Phialophora verrucosa, Cladosporium carrioni and more rarely Rhinocladiella aquaspersa [2].

In nature, these agents live decomposing a organic matter of soil substrates, plant remains, contaminated water, among others. The frequent contact between man and enviromeent facilitates the appearing of this fungal infection [3].

The presence of a papular lesion of erythematous and desquamative surface is initially observed at the site of implantation of CBM agents and may gradually increase in size. Afterwards, a remarkable clinical polymorphism is usually observed, having lesions with the folowing aspects: nodular, verrucous, plaque (infiltrative), tumoral and scarring [4].

The symptomatology commonly described by patients includes the sensation of pain and pruritus (tingling) [3], usually affecting the lower limbs unilaterally [5]. Originally described in 1914 by Pedroso and Gomes in São Paulo, chromomycosis has a worldwide distribution, being more prevalent in tropical and subtropical countries, notably in Brazil, Mexico, Cuba and the Dominican Republic. Climatic conditions associated with underdeveloped regions contribute to maintaining endemic areas well characterized [6]. This study aims to describe demographic and clinical aspects of chromoblastomycosis patients treated at the dermatology department of the Para State University.

\section{Methods}

Twelve patients diagnosed between 2007 to 2017 with chromoblastomycosis, were interviewed at the Dermatology departament of Para State University. Iniatilly, the diagnose was based in the clinical examination, but it was later confirmed with histopatological examination and direct mycological examination. A clinical interview and a der- matological protocole were applied, containing variables as: residence, occupation, lesion aspect, severity, and evolution. The patients signed an Informed Consent Term (TCLE), and those who were unable to attend in person or be legally represented, the face-to-face interview was replaced for the patients form and a Term of Consent for Data Use was applied.

The clinical classification was made based on clinical criteria described and proposed by Carrión in 1950 [7] (Table 1). Whenever there was more than one type of clinical appearance in the same lesion, the predominant one was considered. The classification of lesions according to Queiroz-Telles [8], was also considered, graduating lesions according to their time and severity and dividing them into Light, Moderate and Severe (Table 2).

Table 1. Adaptation of Carrión's clinical classification (1950).

\begin{tabular}{|l|l|}
\multicolumn{1}{c|}{ Type } & \multicolumn{1}{c}{ Description } \\
\hline Nodular & $\begin{array}{l}\text { elevated lesions, } 1 \text { to } 3 \mathrm{~cm} \text {, with fibroelastic } \\
\text { consistency. Erythematous or violaceous } \\
\text { surface, with scaly appearance. }\end{array}$ \\
\hline Tumoral & $\begin{array}{l}\text { large lesion, more than } 3 \mathrm{~cm} . \text { They result } \\
\text { from the coalescence of nodules forming a } \\
\text { pseudotumoral lesion. }\end{array}$ \\
\hline Verruciform & $\begin{array}{l}\text { exophytic lesions, usually large, dry and of } \\
\text { firm consistency }\end{array}$ \\
\hline Scarring & $\begin{array}{l}\text { flat, centrifugal growth, leaving central areas } \\
\text { of epidermis with atrophic or sclerosing } \\
\text { scarring. }\end{array}$ \\
\hline $\begin{array}{l}\text { Plaque } \\
\text { (Infiltrative) }\end{array}$ & $\begin{array}{l}\text { slightly elevated, evenly infiltrated areas. } \\
\text { Erythematous or violaceous staining, the } \\
\text { surface may be scaly. }\end{array}$ \\
\hline $\begin{array}{l}\text { Plaque } \\
\text { (Infiltrative) }\end{array}$ & $\begin{array}{l}\text { slightly elevated, evenly infiltrated areas. } \\
\text { Erythematous or violaceous staining, the } \\
\text { surface may be scaly. }\end{array}$ \\
\hline
\end{tabular}

\section{Results}

After the data analysis, the presented sample was composed mostly of rural residents (75\%), farmers $(66.7 \%)$, with vegetative verrucous lesion (66.7\%), 
classified in the moderate severity category (50\%). And when it comes about the disease evolution time its was found a tie between two distinct groups: less than 5 years (33.3\%) and between 6 and 10 years (33.3\%).

Table 2. Queiroz-Telles's severity graduation (2003).

\begin{tabular}{|c|c|}
\hline Score & Description \\
\hline Light & single lesion with $5 \mathrm{~cm}$ of diameter. \\
\hline Moderate & $\begin{array}{l}\text { solitary or multiple lesions: nodules, verruciform } \\
\text { lesions, plaques, which may exist alone or in } \\
\text { combination, covering one or two adjacent skin } \\
\text { regions measuring less than } 15 \mathrm{~cm} \text { in diameter. }\end{array}$ \\
\hline Severe & $\begin{array}{l}\text { any type of injury alone or in combination, } \\
\text { covering an extensive region of the skin with } \\
\text { adjacent or non-adjacent lesions, and more } \\
\text { than } 15 \mathrm{~cm} \text { in diameter. }\end{array}$ \\
\hline
\end{tabular}

Table 3. Patients' profile with chromoblastomycosis concerning city.

\begin{tabular}{|l|c|c|}
\hline \multicolumn{1}{|c|}{ City } & $\mathbf{n}^{\circ}$ & $\%$ \\
\hline Belém & 3 & 25 \\
\hline Tailândia-PA & 2 & 16.7 \\
\hline Bragança & 1 & 8.3 \\
\hline Piraba & 1 & 8.3 \\
\hline São Miguel do Guamá & 1 & 8.3 \\
\hline Abaetetuba & 1 & 8.3 \\
\hline Marapanim & 1 & 8.3 \\
\hline Igarapé Miri & 1 & 8.3 \\
\hline Cametá & 1 & 8.3 \\
\hline Total & 12 & 100 \\
\hline
\end{tabular}

Source: Research protocole.

Table 4. Patients' profile with chromoblastomycosis concerning occupation.

\begin{tabular}{|l|c|c|}
\hline \multicolumn{1}{|c|}{ Ocuppation } & $\mathbf{n}^{\mathbf{0}}$ & $\%$ \\
\hline Retired & 2 & 16.7 \\
\hline Trader & 1 & 8.3 \\
\hline Farmer & 8 & 66.7 \\
Unemployed & 1 & 8.3 \\
\hline Total & 12 & 100 \\
\hline & Source: Research protocole. \\
\hline
\end{tabular}

Table 5. Patients' profile with chromoblastomycosis concerning the lesion aspect.

\begin{tabular}{|l|c|c|}
\hline \multicolumn{1}{|c|}{ Lesion aspect } & $\mathbf{n}^{\mathbf{0}}$ & $\%$ \\
\hline Infiltrative & 2 & 16.7 \\
\hline Vegetative verrucous & 8 & 66.7 \\
\hline Atrofic & 2 & 16.7 \\
\hline Total & 12 & 100 \\
\hline
\end{tabular}

Table 7. Patients' profile with chromoblastomycosis concerning the disease evolution time.

\begin{tabular}{|l|c|c|}
\hline \multicolumn{1}{|c|}{ Disease evolution time } & $\mathbf{n}^{\mathbf{0}}$ & $\%$ \\
\hline$<5$ years & 4 & 33.3 \\
\hline 6 to 10 years & 4 & 33.3 \\
\hline 11 to 19 years & 0 & 0 \\
\hline 20 to 30 years & 3 & 25 \\
\hline Not registered & 1 & 8.3 \\
\hline Total & 12 & 100 \\
\hline
\end{tabular}

Table 6. Patients' profile with chromoblastomycosis concerning the severity.

\begin{tabular}{|l|c|c|}
\hline \multicolumn{1}{|c|}{ Severity } & $\mathbf{n}^{\circ}$ & $\%$ \\
\hline Light & 2 & 16.7 \\
\hline Moderate & 6 & 50 \\
\hline Severe & 4 & 33.3 \\
\hline Total & 12 & 100 \\
\hline & Source: & Research protocole. \\
\hline
\end{tabular}

Figure 1: cromoblastomicosis lesions according to Carrión's classification.

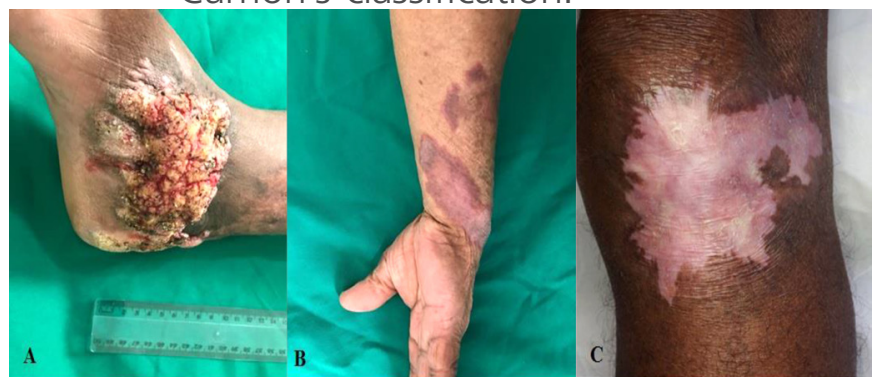

A: verrucifrome lesion; B: infiltrative lesion; C: scarring lesion. Source: research protocole 


\section{Discussion}

Regarding the origin of these patients (Table 3), in individual values, the city of Belém was the one that had more patients (3 patients), Tailandia had 2 patients and the other localities 1 patient each. Belém, the capital, urban district and biggest city in the state, may have present the highest number of cases because the clinic is located in this city, which facilitates the search for care. When analyzed in "rural vs. urban" environments, it's possible to notice that the rural population had a total of 9 patients, while the urban one had only 3 patients, reinforcing the important factor that the rural environment represents in the exposure to the development of the disease [6]. Regarding the occupations (Table 4), the most affected patients were those with occupancy related to frequent soil management, with farmers being the most prevalent, representing 8 patients. 2 patients declared themselves retired and 1 patient declared him as a trader, but all three had previous history of soil manipulation, there is also a patient who declared himself unemployed, who was homeless and garbage collector and also with a history of trauma. Such an occupational profile can be justified by the fact that the fungus that causes the disease can be found in nature in plants and on land and is introduced into the body through traumas or injuries [3], however this traumatic cutaneous injury is often not remembered or perceived by the patient [9]. Therefore, the present study demonstrated that most patients with chromoblastomycosis have or had constant contact with the soil, coming in line with the already established profile of the disease in literature [10]. Regarding the lesion's aspect (Table 5), the clinical classification adopted was based on the criteria described and proposed by Carrión [7]. Whenever there was more than one type of clinical aspect in the same lesion, it was considered the predominant one. In the present study there were no representats of nodular and tumoral type. The verrucous type, however, was the dominant one, with 8 patients, representing almost 70\% of the sample. The infiltrative spectrum and the atrophic aspect had 2 representatives each. This information agrees with a study conducted by Pires [11], with 65 chromoblastomycosis's patients from Eastern Amazonia, showing more than 55\% of the patients presenting verruciform lesions. This finding is in agreement with several publications in the literature, as, for example, the studies of Matte [12], Minotto [13] and Silva [14], disagrees with some studies, such as the one conducted in Mexico by Bonifaz [15], that reported a predominance of nodular lesions.

Regarding the lesions's classification (Table 6), the graduation of Queiroz-Telles was considered [8]. The majority of patients were classified as moderate, totalizing 6 patients. Disagreeing with the study by Mouchalouat [16], which showed that most cases were classified as severe. This disagreement may be due to the fact that the work by Mouchalouat [16], had a larger sample, besides, half of the patients had more than 10 years of disease evolution, which differs from the situation of this present study. Regarding the duration of the disease (Table 7), the delay in diagnosis may be caused due to the fact that chromoblastomycosis has an insidious evolution, which initially may only be asymptomatic lesions that generally do not interfere with the patient's activity, but with time, the itching becomes the predominant symptom of the disease and may be accompanied by local pain. Because it is very itchy, the hypothesis presumes that the spread of the disease to other sites of the skin usually occurs by autoinoculation and/or contiguous lymphatic dissemination [17]. The patients were divided into groups according to their reports and it was observed that there is a big variety of evolution time, from patients with a time of evolution of less than 5 years, to patients with 30 years of evolution. This result is in agreement with the data obtained by Mouchalouat [16] who verified a disease time variable between 8 months and 32 years, which can be attributed to 
the insidious, chronic and initially asymptomatic nature of the disease. Regarding the disease evolution time, in this present study, it was found a tie between two distinct groups: less than 5 years (33.3\%) and between 6 and 10 years (33.3\%) of evolution.

\section{Conclusion}

The profile of the studied population showed, above all, farmers, from rural zones, classified in the moderate severity category, with vegetative verrucous lesions. Concerning the disease evolution time it's was found a tie between two distinct groups: less than 5 years and between 6 and 10 years.

\section{Acknowledgments}

We are grateful for the allowed of the patients attended in the Dermatology Department of the University of the State of Pará to collect their data in this service.

\section{Contribution}

Suzana Ferreira; Anderson Azar; Rafael Chaves; Marcella Maia; Gabriela Rocha; Heraldo Neto; Ana Carolina Nascimento; Márcia dos Prazeres; Samira Oliveira Silveira; Yan Garcia Lira; Mylla O'de Almeida; Fernanda Santos; Victor dos Santos: review of literature, data collect, interpretation of data, writing and concept of the manuscript.

Carla Pires: Concept and orientation of the manuscript, obtaining data and methodological review of the manuscript.

\section{Fundings}

The authors declare having had no financial support.

\section{Conflict of interest disclosures}

The authors declare that there are no conflicts of interest in this study.

\section{References}

1. Siqueira, IM. Imunopatologia da cromoblastomicose: modulação da resposta inflamatória por formas do fungo fonsecaea pedrosoi e seu impacto na cromoblastomicose murina. 2016. Repositório de dados da UNB. Disponível em: repositorio.unb. br/handle/10482/21140. Acessado em: 13 jan. 2016.

2. Daboit, TC. Nanoemulsões de anfotericina B e itraconazol: avaliação da atividade antifúngica in vitro e in vivo em agentes da cromoblastomicose. 2013. Disponível: http://www. lume.ufrgs.br/bitstream/handle/10183/143339/000882701. pdf? sequence=1. Acessado em: 13 jan. 2016.

3. de Almeida, APM, et al. cromomicose: relato de caso e revisão da literatura. Rev Soc Bras Clin Med, v. 12, n. 1, p. 69-71, 2014.

4. Azad, K, et al. Cladophialophora carrionii: an aetiological agent of cutaneous chromoblastomycosis from a non-endemic area, North India. Mycoses, v. 54, n. 4, p. e217-e219, 2012.

5. Martínez, RL; Tovar, LJM. Chromoblastomycosis. Clinics in dermatology, v. 25, n. 2, p. 188-194, 2007.

6. Queiroz-Telles, F. Chromoblastomycosis: A Neglected Tropical Disease. Revista do Instituto de Medicina Tropical de São Paulo, v. 57, p. 46-50, 2015

7. Carrión, AL. Chromoblastomycosis. Annals of the New York Academy of Sciences, v. 50, n. 10, p.1255-1282, 1950.

8. Queiroz-Telles, F, et al. Subcutaneous mycoses. Infectious disease clinics of North America, v. 17, n. 1, p. 59-85, 2003.

9. Queiroz-Telles, F, et al. Chromoblastomycosis. Clinical Microbiology Reviews, v. 30, n. 1, p. 233-276, 2017.

10. Ameen, M. Chromoblastomycosis: clinical presentation and management. Clinical and Experimental Dermatology, 34: 849854. 2009. doi:10.1111/j.1365-2230.2009.03415.x

11. Pires CA, Simoes-Quaresma JA, Moraes-de Macedo GM, Brasil-Xavier M, Cardoso-de Brito A. Revisiting the clinical and histopathological aspects of patients with chromoblastomycosis from the Brazilian Amazon region. Arch Med Res. 2013; 44:302-6

12. Matte SMW, Lopes JO, Melo IS, Espadim LER, Pinto MS. Cromoblastomicose no Rio Grande do Sul: Relato de 12 casos. Rev Soc Bras Med Trop. 1997;30:309-11

13. Minotto R, Bernardi CDV, Mallmann LF, Edelweiss MIA, Scroferneker ML. Chromoblastomycosis: a review of 100 cases in the state of Rio Grande do Sul. J Am Acad Dermatol. 2001;44:585-92 
14. Silva ACCM, Serra NA, Galväo CES, Marques SG, Saldanha $A C R$, Silva CMP, et al. Cromoblastomicose produzida por Fonsecaea pedrosoi no Estado do Maranhão: I - aspectos clínicos, epidemiológicos e evolutivos. Rev Soc Bras Med Trop. 1992;25:37-44

15. Bonifaz, A.; Carrasco-Gerard, E.; Saul, A. Chromoblastomycosis: clinical and mycologic experience of 51 cases. Mycoses, v. 44, n. 1-2, p. 1-7, 2001

16. Mouchalouat, MF. Cromoblastomicose. Estudo de uma série de 14 casos atendidos no Instituto de Pesquisa Clínica Evandro Chagas-Fundação Oswaldo Cruz, Rio de Janeiro, de 1994 a 2005. 2008. Tese de Doutorado. Instituto de Pesquisa Clínica Evandro Chagas.

17. Silva, KLP, et al. Caracterização dos mecanismos de captação de ferro em Fonsecaea pedrosoi e Cladophialophora carrionii. 2017.

Publish in International Archives of Medicine

International Archives of Medicine is an open access journal publishing articles encompassing all aspects of medical science and clinical practice. IAM is considered a megajournal with independent sections on all areas of medicine. IAM is a really international journal with authors and board members from all around the world. The journal is widely indexed and classified Q2 in category Medicine. 